The Historical Journal, 62, 2 (2019), pp. 399-425 C Cambridge University Press 2018. This is an Open Access article, distributed under the terms of the Creative Commons Attribution licence (http://creativecommons.org/licenses/by/4.o/), which permits unrestricted re-use, distribution, and reproduction in any medium, provided the original work is properly cited. doi:10.1017/Soo1 $8246 X_{1} 8000067$

\title{
REASSESSING FRONTLINE MEDICAL PRACTITIONERS OF THE BRITISH CIVIL WARS IN THE CONTEXT OF THE SEVENTEENTH-CENTURY MEDICAL WORLD*
}

\author{
IS M I N I PELLS \\ University of Leicester
}

ABSTRACT. Medical provision in Civil War armies has generally suffered a poor reputation. Medical matters have been excluded from assessments of how far Civil War armies confirm evidence of the so-called 'Military Revolution', whilst Harold Cook argued that it was not until after the Glorious Revolution that the medical infrastructure of the armed forces was brought in line with continental practices, particularly those of the Dutch army. Despite the recent rehabilitation of early modern practitioners elsewhere, frontline military practitioners continue to be dismissed as uneducated, unskilful and incompetent. This is largely due to the lack of a fresh perspective since C. H. Firth published Cromwell's Army in 1902. This article argues that the English were well aware of current medical practice in European armies and endeavoured to implement similar procedures during the Civil Wars. Indeed, almost all the developments identified by Cook for the later seventeenth century can be found in Civil War armies. Whilst failures may have occurred, most of these can be attributed to administrative and financial miscarriages, rather than ignorance of contemporary medical developments. Moreover, there is little to suggest that medics mobilized for Civil War armies were any less capable than those who practised civilian medicine in this period.

Centre for English Local History, University of Leicester, Marc Fitch House, 5 Salisbury Rd, Leicester LEI 7QR Ismini.pells@leicester.ac.uk

* I am very grateful to Jonathan Barry and Peter Elmer for their encouragement and for reading drafts of this article, as well as to Margaret Pelling for many helpful discussions on some of the themes discussed here. I would also like to thank the anonymous referees of the Historical Journal for their comments and helpful suggestions on earlier drafts. This article draws on research undertaken whilst a postdoctoral research associate on the Wellcome Trust-funded project 'The Medical World of Early Modern England, Wales and Ireland, c. $15^{\mathrm{OO}-1715^{\prime}}$ at the University of Exeter (grant reference number $097782 / \mathrm{Z} / 11 / \mathrm{Z}$ ). I am hugely indebted to Anne Laurence for making her research into the army pay warrants in The National Archives (TNA), SP 28 available to the project. This article is based on archival materials publicly available in a variety of repositories, as specified in the footnotes. No new data was created for this article. 
In 1676 , Richard Wiseman recalled an incident from his days as a surgeon in the royalist armies during the British Civil Wars. Following the siege of Taunton, he was called upon to treat a man whose

Face, with his Eyes, Nose, Mouth, and forepart of the Jaws, with the Chin, was shot away, and the remaining parts of them driven in. One part of the Jaw hung down by his Throat, and the other part pasht into it. I saw the Brain working out underneath the lacerated Scalp on both sides between his Ears and Brows.

Faced with this horrific scene, Wiseman noted simply that he 'was somewhat troubled where to begin'. ${ }^{1}$ Many new challenges faced the medical personnel deployed in the Civil Wars, the English sphere of which represented the first significant conflict in that country for over 100 years. Civil War armies were reasonably large by contemporary standards and casualty figures were high. ${ }^{2}$ Technological advances had led to the development of more sophisticated weaponry, with greater and more accurate killing power, whilst many who survived suffered from terrible wounds. 3

A key feature of the so-called 'Military Revolution' of the early modern period was the emergence of armies raised on a larger and more permanent scale, supported by greater financial and bureaucratic mechanisms. In assessing how far Civil War armies confirm evidence of the Military Revolution in Britain during this period, the historiography has focused on issues such as drill, discipline, equipment, organization, funding, and supply. ${ }^{4}$ The issue of medical provision within this context has largely been ignored. Yet, if the Military Revolution in Britain is to be fully assessed, then the influence of continental knowledge and practice upon army medical services must also be considered. Quality medical care was vitally important in influencing an army's fighting capacity, and the strategic and tactical choices available to its commanders. ${ }^{5}$ Harold Cook argued that it was after the Glorious Revolution that the medical infrastructure of the British armed forces was brought in line with continental practices, particularly those of the Dutch army, though he conceded that the transformation 'had its roots in previous decades'. ${ }^{6}$ In fact, as this article will demonstrate, almost all the developments identified by Cook can be found in Civil War armies.

By far the most comprehensive study of Civil War medical provision is from Eric Gruber von Arni, which is particularly successful in utilizing the archives of parliament's permanent military hospitals of the Savoy and Ely House to

${ }^{1}$ R. Wiseman, Severall chirurgicall treatises (London, 1676 ), p. 402.

${ }^{2}$ E. Gruber von Arni, Justice to the maimed soldier (Nottingham, 2015), p. 8.

3 R. A. Gabriel, Between flesh and steel (Washington, WA, 2013), p. 1.

4 A. Hopper, 'The armies', in M.J. Braddick, ed., The Oxford handbook of the English Revolution (Oxford, 2015), p. 267.

5 Ibid., p. 261.

${ }^{6}$ H.J. Cook, 'Practical medicine and the British armed forces after the "Glorious Revolution", Medical History, 34 (1990), pp. 1-26, at pp. 1 and 26. 
provide an authoritative account of hospital care and nursing during the wars. However, he devoted less attention to regimental medical staff or how medical developments in the wars related to long-term developments in the military. If his argument that the Civil Wars 'elicited a dramatic improvement' in the medical care afforded to military casualties is to be accepted, then more consideration needs to be given to the personnel who delivered day-to-day treatments to Civil War armies in the field. 7 Writing in 1902, C. H. Firth expressed a rather uncomplimentary opinion of these men, regarding the large majority as 'not remarkably skilful' and some 'notoriously incompetent'. 8 Seventy years later, Clive Holmes was in agreement. 9 Even Gruber von Arni regarded army surgeons as 'the least competent members of the trade'. ${ }^{10}$ As Margaret Pelling argued, the eccentric behaviour of early modern practitioners was exaggerated by nineteenth-century writers to distance themselves from the past, whilst modern medicine represented the ideal. ${ }^{11}$ The lack of a fresh perspective since Firth's time has simply perpetuated his views. ${ }^{12}$

This article will argue that like other technological and tactical aspects of the Military Revolution, the English were well aware of current medical practice in European armies and endeavoured to implement similar procedures during the Civil Wars. Most failures can be attributed to administrative and financial miscarriages, rather than ignorance of contemporary medical developments. Moreover, there is little to suggest that medics mobilized for Civil War armies were any less capable than those who practised civilian medicine in this period. Unfortunately, due to discrepancies in the surviving evidence, this article has a significant bias towards the larger parliamentary armies but royalist comparisons and examples from parliament's other regional armies and garrisons will be used where possible.

Theoretically, each of the parliamentarian armies had one or two physicians, one or two surgeons, and an apothecary attached to the general staff, whilst each regiment had its own surgeon assisted by two mates. Like many of the military reforms of this period, this arrangement was based on that employed by the Dutch army in the Eighty Years War. ${ }^{13}$ It was the system that Cook noted that

7 Gruber von Arni, Justice to the maimed soldier, p. 2.

8 C. H. Firth, Cromwell's army (London, 1962), pp. $254^{-5}$. This work was originally published in 1902 .

9 C. Holmes, The Eastern Association in the English Civil War (London, 1974), p. 174.

${ }^{10}$ Gruber von Arni, Justice to the maimed soldier, p. 43.

11 M. Pelling, The common lot (Harlow, 1998), pp. 232-4.

12 C. Carlton, Going to the wars (London, 1992), pp. 226-8; Gabriel, Between flesh and steel, p. 71; K. Roberts, Cromwell's war machine (Barnsley, 2013), p. 122.

13 British Library (BL), Kings MS 265 , fos. $44 \mathrm{v}-45^{\mathrm{v}}$ (pay-rates of the Dutch army in $163_{30}$ ); J. Cruso, Militarie instructions for the cavallrie (Cambridge, 1632), p. 24; H. Hexham, The second part of the principles of the art militarie (London, 1638), p. 6 (note irregular pagination). 
'the British were accustomed to expect' by the beginning of William and Mary's reign and, in fact, seems to have been established practice in English armies by the time of the Civil Wars. ${ }^{14}$ A similar scheme was suggested in 1621 for a proposed army intended to recover the Palatinate and was actually employed in the army sent against the Scottish Covenanters in 1639. ${ }^{15}$ The adoption of the Dutch-style model brought English military medical provision in line with one of the foremost European armies of the day. Only the Swedish army of Gustavus Adolphus could boast more regimental medical personnel, with an extra two surgeons per regiment/brigade. ${ }^{16}$ Of course, the medical provision stipulated on paper was not always implemented in practice. As Holmes pointed out, John Lilburne's regiment lacked a surgeon throughout the Eastern Association's northern campaigns in $1644 .{ }^{17}$ In mitigation, efforts were made to cover for absences. Roger Dixon (surgeon to Henry Bulstrode's regiment in the earl of Essex's army) cared for Thomas Tyrell's regiment until Tyrell got a new surgeon and one John Stanley cared for Sir John Meyrick's regiment until John Woodward arrived to take up his appointment. ${ }^{18}$

Parliament also copied the novel concept introduced by the Dutch of paying their troops all year round, not just during the campaigning season. ${ }^{19}$ Interestingly, the remuneration of parliamentarian physicians and apothecaries compares advantageously to their Dutch counterparts. Physicians in the Netherlands received 6 oo guilders a year, which roughly equated to $£ 100 .{ }^{20}$ At the start of the war, the two physicians in Essex's army, Richard Gardiner and Edward Odling, were allocated $6 s 8 d$ a day, which amounts to more than $£ 1$ oo per year. ${ }^{21}$ In spring 1643 , the wage was raised to 10 a day and they were issued with back-dated warrants for the additional pay to the date of

14 Cook, 'Practical medicine and the British armed forces', pp. $4^{-5}$.

${ }_{15}$ F. Grose, Military antiquities (2 vols., London, $1786-8$ ), I, pp. 278 and 370-8; TNA, SP 14 / $119 / 93$ (report presented by the council of war for raising an army for the Palatinate, 13 Feb. 1621 ) fos. 159-64; J. Rushworth, Historical collections (London, 1682), pp. 1046-50.

${ }^{16}$ Gruber von Arni, Justice to the maimed soldier, pp. 5-6; G. Parker, 'The universal soldier', in G. Parker, ed., The Thirty Years' War (London, 1997), p. 183; G. Parker, The army of Flanders and the Spanish Road, 1567-1659 (Cambridge, 2004), pp. 233-5; C. L. Heizmann, 'Military sanitation in the sixteenth, seventeenth, and eighteenth centuries', Annals of Medical History, 1 ( $19^{1} 7^{-}$ 18), pp. 281-300, at pp. 287-94.

17 Holmes, Eastern Association, p. 174.

18 TNA, SP $28 / 127$ fo. 31 ov (Aylesbury garrison accounts, 6 May 1643), SP 28/2B/III fo. $5^{10}$ (pay warrant for John Stanley, 7 Sept. 1642).

19 P. Wilson, Europe's tragedy (London, 2010), p. 145.

${ }^{20} \mathrm{BL}$, Kings MS $26_{5}$, fo. $45^{\mathrm{v}}$. A guilder was comprised of twenty stivers and Cruso's Militarie instructions suggests a conversion rate of six stivers to a shilling. Thus 6oo (guilders) $\mathrm{x} 20=$ 12 , OOO (stivers), which $\div 6=2$, ooo (shillings) i.e. $£ 1$ oo.

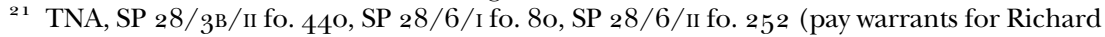
Gardiner, 23 Nov. 1642, 1 Mar. 1643, and 12 Apr. 1643), SP 28/3B/II fo. 442, SP 28/5 fo. 335 (pay warrants for Edward Odling, 23 Nov. 1642 and 28 Feb. 1643). The pay warrants show that the physicians were paid every day, so on a calculation for $36_{5}$ days, their salary would have been $£_{121} 13^{s} 4 d$. 
their commissions. ${ }^{22}$ Thereafter, this was the going rate. ${ }^{23}$ From 1649 onwards, the wage varied, possibly reflecting senior and junior status. For example, of the two physicians to the army for the invasion of Ireland, William French was paid at the $6 s 8 d$ rate but Joseph Waterhouse at 1 os per day. ${ }^{24}$ The apothecaries, who received no daily pay in the Dutch armies, were paid $5^{s}$ a day in the parliamentarian armies, rising to $6 s 8 s$ in 1647 , and sometimes had two assistants at $2 s 6 d$ per day each. ${ }^{25}$ Physicians and apothecaries were also able to claim expenses. ${ }^{26}$

Parliamentarian surgeons were paid the same as those in the Netherlands, who could expect a wage of 25 stivers a day. ${ }^{27}$ The military author John Cruso calculated this equated to 4 , whilst surgeons' mates received the equivalent of $2 s 6 d .{ }^{28}$ Thus, with some exceptions at the start of the war, ${ }^{29}$ this was the pattern settled upon. $3^{\circ}$ The same rates applied to the surgeons on the general staff. $3^{1}$ Those who incurred expenses beyond those which were usually expected received recompense from the public purse, whilst each regimental surgeon received money for a chest of medicaments. ${ }^{32}$ The provision for surgeons' chests, introduced in the Dutch army by 1612, had been brought into

${ }^{22}$ TNA, SP $28 / 7$ fo. 127 (pay warrant for Edward Odling, 26 May 1643 ), SP 28/ 7 fo. 145 (pay warrant for Richard Gardiner, 29 May 1643).

23 For example, TNA, SP 28/12/I fo. 69 (pay warrant for Edward Odling, 5 Feb. 1643/4), SP $28 / 25 /$ III fo. 379 (payment to Henry Glisson (Eastern Association) for 1 Jan. to 26 Feb. 1644), SP 28/29/I fo. 9 (pay warrant for Adam Stryall (New Model), 17 Apr. 1645). Stryall only collected $5^{s}$ a day in accordance with the New Model Ordinance, whereby any officer who received $10 s$ a day or more received half their pay at the time and was issued with a debenture for the rest: Firth, Cromwell's army, pp. 200-1.

${ }_{24}$ TNA, SP 28/62/II fo. 229 (pay warrant for William French, 21 Aug. 1649), SP 28/62/I fo. 40 (pay warrant for Joseph Waterhouse, 30 Aug. 1649).

${ }_{25} \mathrm{BL}$, Kings MS 265 , fo. $45 \mathrm{v}$; TNA, SP $28 / 2 \mathrm{~A} / \mathrm{II}$ fo. 189 (pay warrant for Abraham Webb (Essex's army), 8 Sept. 1642), SP 28/25/III fo. 379 (payment to Thomas Bert (Eastern Association), 20 Dec. 1643 to 28 Feb. 1644), SP 28/36/II fo. 147 (pay warrant for Abraham Webb (New Model Army), 6 Feb. 1645/6); Journals of the House of Lords, x (1648-9), p. 66.

${ }^{26}$ For example, TNA, SP 28/2/IIA fo. 197 (warrant to pay Richard Gardiner, 9 Sept. 1642), SP 28/2A/I fo. 96 (warrant to pay Abraham Webb, 3 Sept. 1642).

${ }_{27}$ BL, Kings MS 265 , fo. $44 \mathrm{v}$.

28 Cruso, Militarie instructions, p. 24.

29 For example, Lawrence Loe/Lowe, Essex's original staff surgeon, was paid $20 s$ a day for himself and two mates: TNA, SP $28 /{ }_{3}$ B/II fo. 499 (pay warrant for Lawrence Loe, 29 Nov. $1642)$. Likewise, the pay warrants issued to the colonels in Essex's army in Aug. 1642 only allowed for $2 s$ a day for the surgeon's mates: TNA, SP $28 / 1$ A fos. 29, $3^{8-9}, 4^{\mathrm{O}-1}, 64,66-9$ (pay warrants for regimental colonels, Aug. 1642).

$3^{\circ}$ For example, TNA, SP 28/3B/II fo. 411 (pay warrant for Roger Dixon (Essex's army), 19 Nov. 1642), SP 28/14/I fo. 180 (account of Thomas Fothergill (Eastern Association), 1 Jan. to 21 Apr. 1644), SP 28/122/III fo. 417 (payment made to Alexander Aurelius (Southern Association), 25 Apr. 1645); SP 28/138/III fo. 4v (Beverley garrison accounts, 1642-3).

$3^{1}$ For example, TNA, SP 28/16/I fo. 108 (pay warrant for Timothy Langley, 26 June 1644), SP 28/15/III fo. 265 (pay warrant for Edward Elsing, 10 May 1644), SP 28/30/II fo. 172 (pay warrant for James Winter, 6 May 1645).

$3^{2}$ TNA, SP 28/41/III fo. 224 (payment to Thomas Fothergill, 21 Dec. 1646), SP 28/1A fos. 29, $3^{8-9}, 4^{--1}, 64,66-9$ (pay warrants for regimental colonels, Aug. 1642). 
English armies by Charles I for the expedition to the Île de Ré in ${ }_{1627}$, though apparently he did not honour the bill. 33

However, it is well known that army wages were far from regularly paid in the Civil Wars.34 Thomas Trapham, surgeon to Philip Skippon's regiment in Essex's army, was forced to petition the House of Commons in October 1644 for his arrears, whilst Lord Willoughby's surgeon, Isaac Demergue, was imprisoned for debt after his arrears were unpaid. 35 The failure to pay and supply regimental medical personnel potentially had a crucial impact on their army's military capabilities. For example, throughout summer 1644, Essex's army suffered from a complete lack of supplies, despite the earl's repeated requests. ${ }^{6}$ By the time his army reached Lostwithiel, frequent deaths hampered their efforts to hold off royalist attacks because the surgeons were 'ill stored with provisions'. 37 On 1 November, four surgeons in Essex's army were referred to the Commissioners for Martial Affairs for ignoring orders to repair to the army shortly before the second battle of Newbury 'to the great Detriment of the Service' $.3^{8}$ Two weeks previously, the neglected state of Essex's surgeons had been a matter of concern and it seems that the $£_{4}$ advance they had received was not enough to convince them that their past and future wages would be honoured. 39

Eric Gruber von Arni argued that the royalists' lackadaisical approach to administration engendered insufficient medical provision but this assessment was based on sparse documentation surviving from the royalist headquarters at Oxford and, as Jonathan Worton highlighted, may not reflect the situation in the king's other armies and garrisons. $4^{\circ}$ Recent historiography has shown that military administration in the king's camp was much more successful than previously thought, though the lack of evidence makes it impossible to tell if a uniform pattern of medical organization and pay existed in royalist armies. $4^{11}$ A pay establishment for the royalist garrison at Worcester in June 1643 allocated

33 G. F. Hildanus, Cista militaris (London, 1674); J. Woodall, The surgeons mate (London, 1639), preface to 'Viaticum, being the path-way to the surgeons chest'; S. Young, The annals of the Barber-Surgeons of London (London, 1890 ), p. 405.

34 Holmes, Eastern Association, pp. 146-7; I. Gentles, The New Model Army (Oxford, 1994), pp. 49 and 239-40; Firth, Cromwell's army, pp. 197-9.

35 Historic Manuscripts Commission, Thirteenth report, appendix, part I (London, 1891), p. 187; Journals of the House of Commons $(J H C)$, III (1643-4), p. 658; TNA, SP $21 / 7$ fo. 227 (Proceedings of the committee of both kingdoms, 9 Oct. 1644); Parliamentary Archives, $\mathrm{HL} / \mathrm{PO} / \mathrm{JO} / 10 / 1 / 177$ (petition of Isaac Demergue, 21 Dec. 1644).

$3^{6}$ M. Wanklyn, The warrior generals (London, 2010), pp. 116-17 and 121.

37 B. Whitelock, Memorials of the English affairs (4 vols., Oxford, 1853), I, p. 3 oo.

$3^{8} \mathrm{JHC}$, III $\left(1643^{-4}\right)$, p. $68_{3}$.

39 Calendar of state papers domestic (CSPD), 1644-5, p. 25.

$4^{\circ}$ Gruber von Arni, Justice to the maimed soldier, pp. 16-31; J. Worton, 'The royalist and parliamentarian war effort in Shropshire during the First and Second English Civil Wars, $1642-$ 1648' (Ph.D. dissertation, University of Chester, 2015), p. 216.

$4^{1}$ M. Wanklyn and F. Jones, A military history of the English Civil War (Abingdon, 2014), p. 18. 
2s $6 d$ per day for one surgeon for every horse regiment. $4^{2}$ During the same period, Sir William Russell (governor of Worcester) paid the surgeon of his foot regiment, Richard Addis, $5^{s}$ a day, money to resupply his chest of medicaments and surgical instruments, and $10 s$ a week for his apprentice (who was presumably acting as his mate). 43 At Lichfield, the surgeons seem to have been paid per cure, whilst Dr Whittaker the physician was paid £1 $5^{s}$ per week.44 Elsewhere, fragmentary remains from a royalist account book suggests a standard rate: £1o each was paid to six surgeons but it is unclear what period of employment this sum covered. 45

\section{I}

Although Firth suggested that the wages paid to parliamentarian physicians were suitable for 'a man of some standing in his profession', he claimed that those offered to surgeons were 'too small to secure really able men'. $4^{6}$ Admittedly, surgeons sometimes found their wages unsatisfactory. In October 1655, Thomas Fothergill (surgeon to the Protector's regiment of horse) claimed his wages were 'farre short of a subsistance'. 47 However, the parliamentarian surgeons' day-rate was the same as that accorded to a lieutenant of a foot regiment: an interesting comparison given that Firth concluded that 'the officers both of horse and foot were well paid'. $4^{8}$ Furthermore, unlike infantry officers' wages, surgeons' wages responded to changes in the economic climate until 1658 , when the Protectoral government was financially over-stretched. 49 At this time in Scotland, George Monck ordered his surgeons to be entered as privates in regimental muster rolls so that they could earn an extra $9 d$ a day. $5^{\circ}$ Surgeons' salaries in the parliamentary armies were certainly more generous than in the navy, where a surgeon received gos a month and his mate $20 s$ a month. $5^{1}$ These rates were raised to $5^{\circ}$ and $30 s$ respectively in $1653 \cdot 5^{2}$

Yet, what makes Firth's claim particularly bold is that it is extremely difficult to discern what a surgeon might expect to be paid in this period. Early modern surgeons (and indeed physicians, though they seldom cared to admit it)

$4^{2}$ J.W. Willis Bund, ed., Diary of Henry Townshend of Elmley Lovett, I640-I663 (2 vols., London, 1920), II, p. 126.

43 Ibid., p. 153.

44 I. Atherton, 'The accounts of the royalist garrison of Lichfield Close, 1643-1645', Staffordshire Studies, 18 (2007), pp. 63-96, at pp. 82-9o.

45 TNA, SP 28/143/III fos. 20a, 66a, and 68a (royalist account book, 19 Mar. to 13 June 1644).

$4^{6}$ Firth, Cromwell's army, pp. 253-4.

47 TNA, SP 18/101 fo. 14 (petition of Thomas Fothergill, 3 Oct. 1655).

$4^{8}$ Firth, Cromwell's army, p. 186.

49 Ibid., pp. $184^{-7}$ and 254 .

$5^{\circ}$ Ibid., p. 254 .

$5^{1}$ J.J. Keevil, Medicine and the navy (2 vols., London, 1957-8), I, p. 213.

$5^{2}$ Ibid., II, p. 8. 
earned their living on a case-by-case basis by negotiating a contract with their patient (or the patient's family or friends), in which the practitioner received an agreed fee in return for the time their patient spent under their cure.53 The fees agreed would vary according to the severity of the condition and the length of time over which treatment was administered. Contracts that appear lucrative at first sight often masked the fact that the surgeon might be treating the patient for several years. 54 Salaried positions were unusual and where they existed, a practitioner expected to supplement this with other commissions. 55 Surgeons stationed in garrison towns, for example, may have acquired clients from the civilian population upon whom they were billeted. As Cook noted, the prominence of a military position provided the opportunity to build up contacts and reputation, both of which might be used to expand a surgeon's civilian practice when he left the army. $5^{6}$ Anne Digby demonstrated that at least from the eighteenth century, state-salaried positions were eagerly contested, despite sometimes low wages. 57 The dangers and hardships of war may have made army positions less attractive than state positions, but for those prepared to brave the risk, there were rewards to be had.

Indeed, loyalty to a cause brought the promise of material rewards beyond simple wages. Even surgeons like Trapham might be rewarded with an honorary MD, whilst after the Restoration, John Knight (surgeon to Prince Rupert's forces at Leicester in 1645 ) was appointed serjeant-surgeon to Charles II. $5^{8}$ On 16 July 1649, the Commons passed an act enabling those who had served in their armies to use their pay debentures to purchase crown lands. 59 Trapham redeemed his debentures to acquire parcels of land in Lincolnshire. ${ }^{60}$ Likewise, Daniel Judd, surgeon to Sir Arthur Hesilrige's regiment in the New Model Army, purchased several messuages in Middlesex. ${ }^{61}$ The acquisition of land brought the benefits of status, diversification of income and investment. Furthermore, like other officers, surgeons brought debentures well below their face-value from soldiers (for whom ready cash was more attractive) to acquire sizeable estates. ${ }^{62}$ Judd used eight soldiers' debentures to secure his purchases in Middlesex valued at $£_{1} 8_{4} 14^{s}$, whilst

53 M. Pelling, Medical conflicts in early modern London (Oxford, 2003), pp. 246 and 267-9.

${ }^{54}$ Ibid., pp. $263-5$.

55 Pelling, Common lot, p. 89 .

$5^{6}$ Cook, 'Practical medicine and the British armed forces', p. 8.

57 A. Digby, Making a medical living (Cambridge, 1994), pp. 5o, 119 , and 230.

${ }_{5}^{8}$ C. Webster, The Great Instauration (London, 1975), p. 293; C. S. Knighton, 'Knight, John (bap. 1622, $d .1680$ )', Oxford dictionary of national biography (ODNB).

${ }_{59}$ C. H. Firth and R. S. Rait, eds., Acts and ordinances of the Interregnum, I642-I66o (3 vols., London, 1911), II, pp. 168-91.

6o TNA, $121 / 3 / 3 / 118-119$ (certificates of sales of crown lands to Thomas Trapham, 18 May 1653 and 26 May 1653$)$.

61 TNA, E $121 / 3 / 4 / 95$ (certificate for sale of crown land to Daniel Judd, 14 Feb. 1652).

${ }^{62}$ I. J. Gentles, 'The debentures market and military purchases of crown land, 1649-166o' (Ph.D. dissertation, London, 1969), pp. $7^{\circ}-9$. 
more spectacularly, Henry Cleare and his son, also Henry, brought the manors of Ennerdale in Cumberland and Radnage in Buckinghamshire for $£_{1,278} 19 \mathrm{~s}$ $9 d$ using thirty-seven soldiers' debentures. ${ }^{6} 3$

All this said, to suggest that meagre wages might put off able surgeons from joining Civil War armies presumes that such men would have only been attracted to the service by financial benefits. It is true that in some cases, parliament resorted to impressing surgeons and certainly individuals impressed to be soldiers were often unskilled or unsuitable men. ${ }^{6} 4$ The same situation may have applied to impressed surgeons. However, for those who willingly volunteered, higher ideals may have over-ridden material concerns. Lawrence Loe, the earl of Essex's first staff surgeon, seems to have shared his master's objectives for the parliamentarian coalition. He apparently allied himself to the Presbyterian movement in London, which looked to the earl for leadership until Essex's death in $1646 .{ }^{6}$ Thomas Burton, surgeon to the Southwark White Auxiliaries of the London Trained Bands, was described in $165^{2}$ by no less a man than Oliver Cromwell as 'very honest and faithfull to the interest of the Commonwealth'. ${ }^{66}$ Preambles couched in distinctly godly language preface the wills of parliamentarian surgeons John Anthony, Jonathan Crosse, Bradbury Clarke, and Henry Barnwell. ${ }^{67}$ Perhaps more instructively, a number of former parliamentarian surgeons were practising non-conformity at the Restoration. The two Cleares were prosecuted for attending a Presbyterian conventicle at Kingston-upon-Thames in 1677 and Edward Atkinson was a close friend of the Socinian preacher John Knowles. ${ }^{68}$ In ${ }_{1665}$, Atkinson wrote a heart-breaking letter to Knowles following the death of his 'Deare, Deare, Deare wife' in which he took comfort in the 'great Satisfacc[i] on' she had found in attending the Independent congregation led by George Griffith in London during her last months. ${ }^{69}$

Conversely, when William Clowes, serjeant-surgeon at the royalist army's headquarters in Oxford, begged to compound for his estates in 1646 , he presented his royalism as an inevitability as the king's 'sworn servant and

63 TNA, E $121 / 3 / 4 / 95$; TNA, E $121 / 5 / 7 / 36$ (certificate for sale of crown land to Henry Cleare, 20 Nov. 1650 ).

${ }^{64}$ Firth and Rait, eds., Acts and ordinances, I, pp. 241-2; Carlton, Going to the wars, p. 68.

65 T. Liu, Puritan London (London, 1986), p. 134; K. Lindley and D. Scott, eds., The journal of Thomas Juxon, I644-I647 (London, 1999), p. 21.

66 TNA, SP 28/121A/III fo. 339 (muster roll of the Southwark White Auxiliaries, 16 Apr. 1644); London Metropolitan Archives, Ho1/ST/A/o67/oo1/19 (letter from Oliver Cromwell to St Thomas's Hospital, $\left.165^{2}\right)$.

${ }_{7}$ TNA, PROB $11 / 267$ fos. 250v-251 (will of John Anthony, 17 Sept. 1657), PROB $11 / 211$ fos. $31 \mathrm{v}^{-} 3^{2}$ (will of Jonathan Crosse, 25 Jan. 165o), PROB $11 / 3^{15}$ fos. $179^{-1} 80$ (will of Bradbury Clarke, 25 Nov. 1664), PROB $11 / 293$ fo. 20 (will of Henry Barnwell, 25 June 1659).

${ }^{68}$ Surrey History Centre, QS2/5/1677, m. 19 (Quarter Sessions Roll, Easter 1677); J. Foster, Alumni Oxonienses, I5oo-I7I4 (4 vols., Oxford, 1891), I, p. 41; CSPD, 1655-6, pp. $113^{-14}$.

69 TNA, SP 29/119/26/vi fo. 62 (letter from Edward Atkinson to John Knowles, 25 Apr. 1665). 
surgeon for these $4^{\mathrm{o}}$ years' $7^{\circ}$ A more eccentric expression of royalism allegedly came from Edward Molins. Molins served as a surgeon with the royalist forces from the beginning of the war until he was captured at the siege of Arundel in January 1644 . Nevertheless, his reputation as a lithotomist was such that Cromwell sought his treatment when suffering from a bladder stone in $165^{6.7^{1}}$ The Genovese ambassador, a friend of Cromwell, reported that Molins gave Cromwell a draught to relieve the pain and then turned him upside down three times in imitation of how Molins claimed the Protector had treated England. Molins refused any payment but asked for a drink, which he then used to toast King Charles. $7^{2}$

It was not only surgeons of whom Firth held a low opinion. He also questioned whether the physicians were sufficiently qualified because few were fellows of the College of Physicians. 73 As Table 1 shows, that much can be verified. However, Margaret Pelling has shown that in the seventeenth century there was 'a lack of real difference in educational attainment between Fellows and a significant number of outsiders'. 74 The College's role was simply to license practitioners of physic within a seven-mile radius of London and so prosecution of those who practised without their licence took precedence over other activities such as literary production or anatomy lectures. 75 Moreover, although the most important academic centres for medical learning were located abroad, the College limited those with qualifications from foreign universities to becoming licentiates and censored continental authors in favour of the classical greats. $7^{6}$

Considering Gruber von Arni's assertion that the number of graduate physicians in England was 'abysmally low' at this time, then Table 1 might give a brighter view of Civil War physicians' educational credentials. 77 That said, university was not the only method of qualification. Many physicians learnt by apprenticeship and even university-educated physicians increasingly undertook practical apprenticeships alongside academic study. $7^{8}$ In fact, former Civil War soldier-turned-physician Thomas Sydenham recommended apprenticeships over attendance at university for would-be physicians. 79

$7^{\circ}$ M. A. E. Green, ed., Calendar of the proceedings of the committee for compounding, ${ }^{6} 643^{-1} 660$ (5 vols., London, 1889-92), II, p. $15^{67}$.

$7^{1}$ G. C. R. Morris, 'Molins, Edward (1610?-1663)', ODNB.

$7^{2}$ C. Prayer, ed., 'Oliviero Cromwell dalla battaglia di Worcester alla sua morte', Atti Societa Ligure Storia Patria, 16 ( 1882), pp. 366-8; G. C. R. Morris, 'Which Molins treated Cromwell for stone - and did not prescribe for Pepys?', Medical History, 26 (1982), pp. 429-35, at p. 428.

73 Firth, Cromwell's army, p. 254.

74 Pelling, Medical conflicts, p. $14^{2}$.

75 Ibid., pp. 1-2 and 102.

$7^{6}$ Ibid., pp. 142 and $167-8$.

77 Gruber von Arni, Justice to the maimed soldier, p. 11.

$7^{8}$ Pelling, Common lot, pp. 237-8; A. Wear, Knowledge and practice in English medicine, I550I 680 (Cambridge, 200o), p. 471.

79 Pelling, Common lot, p. $23^{8 .}$ 
Table 1 Physicians in Civil War armies

\begin{tabular}{|c|c|c|c|}
\hline Name & Army & $\begin{array}{l}\text { London College of Physicians status } \\
\text { (brackets indicates status after army } \\
\text { service) }\end{array}$ & $\begin{array}{l}\text { Academic qualification } \\
\text { (brackets indicates qualification } \\
\text { after army service) }\end{array}$ \\
\hline $\begin{array}{l}\text { Nathaniel } \\
\text { Chamberlain }\end{array}$ & Earl of Essex & - & BMed Oxford ${ }_{1} 63^{6} 6$ \\
\hline Richard Gardiner & Earl of Essex & - & - \\
\hline John King & Earl of Essex & - & MD Leiden 1629 \\
\hline Paul de Laune & Earl of Essex & Fellow 1618 & MD Padua 1614 \\
\hline Anthony Metcalfe & Earl of Essex & - & - \\
\hline Francis Neville & Earl of Essex & - & - \\
\hline Edward Odling & Earl of Essex & - & $\begin{array}{l}\text { (MD Cambridge } 1632 \text { by royal } \\
\text { letter) }\end{array}$ \\
\hline Dr [John] Pordage & $\begin{array}{l}\text { Earl of Essex (Windsor } \\
\text { garrison) }\end{array}$ & - & MD Leiden 1639 \\
\hline Samuel Read & Earl of Essex & - & Entered Leiden 1632 \\
\hline $\begin{array}{l}\text { Thomas Sheafe (may } \\
\text { not have served) }\end{array}$ & Earl of Essex & Fellow 1637 & MD Cambridge ${ }^{16} 3^{6}$ \\
\hline John St John & Earl of Essex & - & MD Padua 1640 \\
\hline Adam Stryall & $\begin{array}{l}\text { Earl of Essex/New } \\
\text { Model }\end{array}$ & 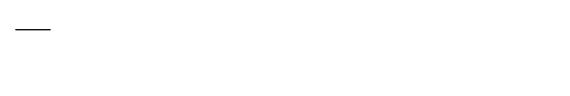 & - \\
\hline Edward Emily & Eastern Association & Licentiate ${ }^{6} 64^{1}$ (Fellow 1647$)$ & MD Leiden 1640 \\
\hline Henry Glisson & Eastern Association & (Honorary Fellow 1664) & MD Cambridge 1639 \\
\hline William Staines & Eastern Association & Fellow 1641 & MD Cambridge 1639 \\
\hline
\end{tabular}




\begin{tabular}{|c|c|c|c|}
\hline Name & Army & $\begin{array}{l}\text { London College of Physicians status } \\
\text { (brackets indicates status after army } \\
\text { service) }\end{array}$ & $\begin{array}{l}\text { Academic qualification } \\
\text { (brackets indicates qualification } \\
\text { after army service) }\end{array}$ \\
\hline John Pratt & Southern Association & $\begin{array}{l}\text { (Candidate } 1649) \text { Had appeared for } \\
\text { examination in } 163^{6} 6 \text { but too few } \\
\text { censors were available }\end{array}$ & MD Cambridge 1645 \\
\hline Henry Hayhurst & Northern Association & - & $\begin{array}{l}\text { No medical degree but BA } \\
\text { Oxford } 1619\end{array}$ \\
\hline John Troutbeck & $\begin{array}{l}\text { ?Northern Association/ } \\
\text { New Model }\end{array}$ & 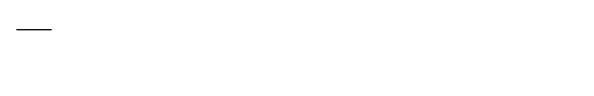 & $\begin{array}{l}\text { (MD Cambridge } 1661 \text { by royal } \\
\text { letter) }\end{array}$ \\
\hline John Baber & New Model & (Candidate $1_{5}{ }^{1}$, Fellow 1657 ) & MD Leiden 1648 \\
\hline Samuel Barrow & New Model & - & - \\
\hline Claudius Fenwick & New Model & - & MD Franeker 1647 \\
\hline John French & New Model & $\begin{array}{l}\text { (Examined for membership } 1648 \text { but } \\
\text { no admittance record) }\end{array}$ & (MD Oxford 1648 ) \\
\hline William French & New Model & - & (MD Cambridge 1647) \\
\hline Jonathan Goddard & New Model & Fellow 1646 & MD Cambridge 1643 \\
\hline Thomas Payne & New Model & - & - \\
\hline John Short & New Model & - & Entered Leiden 1639 \\
\hline Joseph Waterhouse & New Model & - & (Rewarded MD Oxford $165^{1}$ ) \\
\hline Dr Massey & $\begin{array}{l}\text { Plymouth garrison } \\
\text { (parliamentarian) }\end{array}$ & - & $?$ \\
\hline John Hall & $\begin{array}{l}\text { Plymouth garrison } \\
\text { (parliamentarian) }\end{array}$ & - & $?$ \\
\hline Francis Goddard & Oxford Army (royalist) & - & MD Oxford 1641 \\
\hline
\end{tabular}




\section{Samuel Turner \\ Dr Whittaker}

Oxford Army (royalist)

Lichfield Garrison

(royalist)

\section{Padua 1611}

?

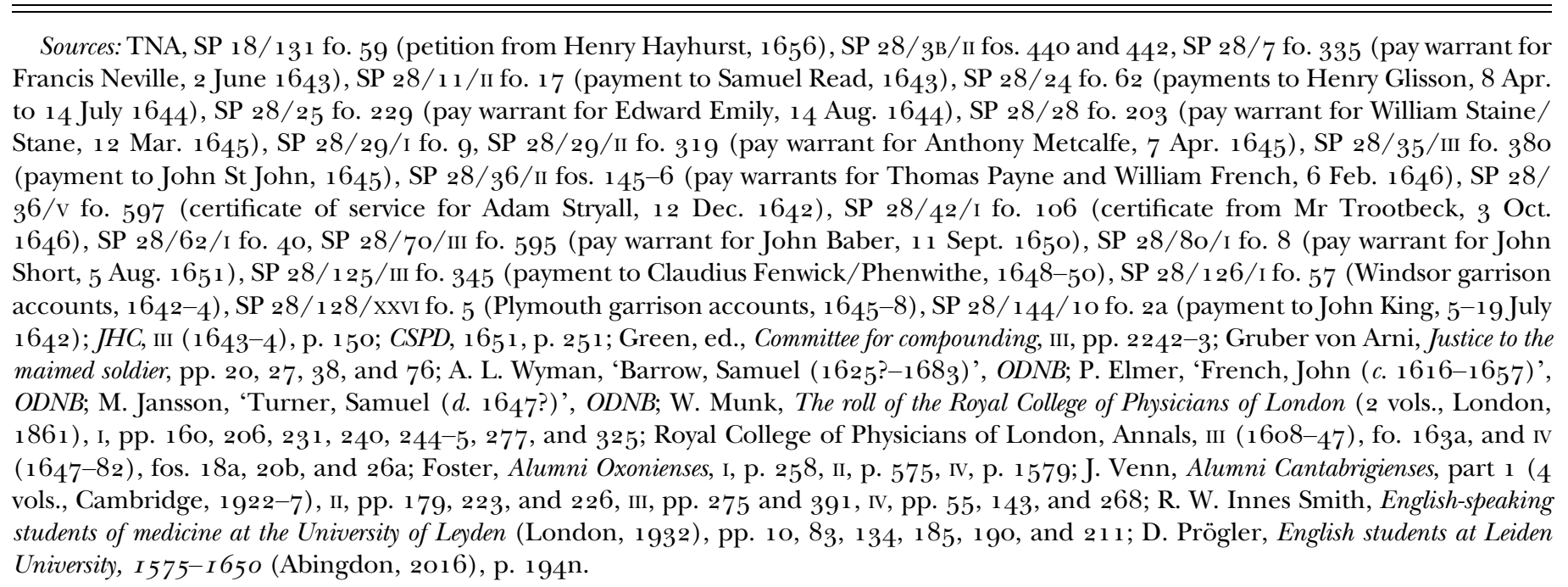


Apprenticeship has suffered from later social devaluation, which might partly explain the negative portrayal of Civil War surgeons, as this was their main method of education. ${ }^{80}$ In the London Barber-Surgeons' Company, apprentices were bound to liverymen for at least seven years, which consisted of onthe-job training accompanied by teaching and personal study. Apprentices were admitted as freemen at the end of their term of service but none was allowed to practise surgery without first being examined by the Company. ${ }^{81}$ Furthermore, regular dissections and lectures took place at Barber-Surgeons' Hall, attendance at which was (apparently) compulsory for all the Company's surgeons. ${ }^{82}$ Tables 2 to 6 give a rough indication of the proportion of Civil War surgeons who were free of the London Barber-Surgeons' Company. ${ }^{8}$ It must be stressed that this evidence should not be used too definitively, as it is sometimes impossible to make clear identifications between a particular Civil War surgeon and a man of the same name in the Barber-Surgeons' Company.

What of the education of the remainder? Taking the Eastern Association as an example, barber-surgeons' companies have been found in Ipswich, Lincoln, Norwich, and St Albans. ${ }^{8} 4$ Furthermore, large numbers of barber-surgeons existed in the sizeable corporate towns of King's Lynn, Colchester, and Great Yarmouth, which suggests that although surgeons did not have their own company, they may have been included in conglomerate companies with related crafts. This was certainly common practice in other parts of the country, such as the north-west. ${ }^{8} 5$ Unfortunately, very few records for these companies survive. ${ }^{86}$ The recording of one 'Andreas Vanderlas' as warden to the Norwich Barber-Surgeons' Company in 1645 provides an intriguing hint that many of the surgeons of the Eastern Association, which was largely raised in the Eastern Counties, may have come through the ranks of East Anglian barber-surgeons' companies. ${ }^{8} 7$ Was this the same Andrew Vanderlash who was surgeon to Sir John Norwich's troop in the Eastern Association and paid out of the Norwich weekly assessment? ${ }^{88}$

80 Ibid., pp. 232 and 237.

${ }^{81}$ Young, Annals of the Barber-Surgeons, p. 260.

82 Ibid., p. 119 .

83 Those made free by methods other than apprenticeship are noted, excepting those made free by patrimony because it is not unreasonable to suggest that they learnt from their surgeon fathers. A Daniel Judd was free of the Company by apprenticeship but served a hotpresser, whilst a Humphrey Hughes was free of the Company by patrimony but his father was a haberdasher, so these have been discounted as the Civil War surgeons until further connections can be made (see Table 5 ).

84 M. Pelling, 'Barber-surgeons' guilds and ordinances in early modern British towns', p. 5, http://practitioners.exeter.ac.uk/, accessed 7 June 2016.

${ }_{5}$ Pelling, Common lot, p. 209.

86 Pelling, 'Barber-surgeons' guilds', pp. 2-3.

87 C. Williams, The masters, wardens, and assistants of the Guild of Barber-Surgeons of Norwich (Norwich, 1900), p. 15 ; Holmes, Eastern Association, p. 164 .

88 TNA, SP 28/26/III fo. 312 (payment to Andrew Vanderlash, 18 Jan. 1645). 
Table 2 Surgeons in the earl of Essex's army

\begin{tabular}{|c|c|c|}
\hline $\begin{array}{l}\text { Freeman of the London } \\
\text { Barber-Surgeons' Company }\end{array}$ & $\begin{array}{l}\text { Identifiable surgeons not in the } \\
\text { London Barber-Surgeons' Company }\end{array}$ & $\begin{array}{l}\text { Other unidentifiable } \\
\text { surgeons }\end{array}$ \\
\hline ?William Alley/Allen & John Anthony & Bromfield \\
\hline James Bricknell & Stephen Beddard & Mapheston \\
\hline ?John Browne & Nicholas Boden & Mr Purlervant \\
\hline [?Thomas] Burton & Matthew Broad & Mr Rondes \\
\hline Henry Cleare Snr & John Broughton & Mr Stanley \\
\hline ?Edward Cooke & John Cleare & \\
\hline Roger Dixon (translated) & James Cooke & \\
\hline John Franklin & James Cooke & \\
\hline Nathaniel Harris & John Fletcher & \\
\hline Nicholas Heath & Peter Francis & \\
\hline Timothy Langley & Meredith Jones & \\
\hline Lawrence Loe & Thomas Kinker & \\
\hline Ralph Nicholson & Thomas Lugg & \\
\hline John Rice & William de Margey (possibly the same man as below) & \\
\hline William Roberts & Isaac de Morgane/Demergue & \\
\hline ?Mr [?Christopher] Southwell & Thomas Noxe & \\
\hline ?James Swright/?Wright & William Parkes & \\
\hline Thomas Symonds & Llewellyn Price & \\
\hline Thomas Trapham & Francis Rishworth & \\
\hline ?Hugh Ward & Peter de Sallenova & \\
\hline James Winter & Richard Searle & \\
\hline ?John Woodward & Isaac Smitheis/Smythes & \\
\hline
\end{tabular}




\begin{tabular}{lll}
\hline \hline $\begin{array}{l}\text { Freeman of the London } \\
\text { Barber-Surgeons' Company }\end{array}$ & $\begin{array}{l}\text { Identifiable surgeons not in the } \\
\text { London Barber-Surgeons' Company }\end{array}$ & $\begin{array}{l}\text { Other unidentifiable } \\
\text { surgeons }\end{array}$ \\
\hline & William Stannard & Richard Thurston \\
& Christopher Tiack \\
John Waylett & Robert Woodward \\
\hline \hline
\end{tabular}

Sources: E. Peacock, ed., The army lists of the roundheads and cavaliers (London, 1874 ), pp. 27-9, 31, 34-5, 37, 42, 44-5, and 48; TNA, SP 28/2A/I fos. 104 and 145 (pay warrants for Richard Thurston, 3 Sept. 1642, and Hugh Ward, 5 Sept. 1642), SP 28/2B/II fos. 42O-1 (pay warrants for James Cooke and James Swright/Wright, 18 Oct. 1642), SP 28/2B/III fo. 534 (commission for Peter Sallenova, Sept. 1642 ), SP 28/3A/I fo. 45 (payment to Thomas Kinker, 9 Nov. 1642), SP 28/3A/III fo. 285 (pay warrant for William de Margey/de Morger, 9 Nov. 1642), SP $28 / 3^{\text {B/I }}$ fo. 397 (pay warrant to Roger Dixon, 18 Nov. 1642), SP $28 / 4$ fos. 175 and $35^{8}$ (pay warrants for Isaac de Morgan/ Demergue, 3 Dec. 1642 , and for Ralph Nicholson, 27 Dec. 1642 ), SP 28/5 fos. 126,31 , and 341 (pay warrants for Henry Cleare, 21 Jan. 1643, John Waylett, 27 Feb. 1643, and Isaac Smitheis/Smythes, 28 Feb. 1643), SP 28/6/I fo. 92 (pay warrant for Thomas Symonds, 1 Mar. 1643), SP 28/6/II fo. 277 (pay warrant for Llewellyn Price, 13 Apr. 1643), SP 28/7 fos. 85 and 316 (pay warrants for Nicholas Heath, 25 May 1643, and John Fletcher, 23 June 1643), SP 28/9 fo. 364 (bill for Francis Rishworth, 21 Aug. 1643), SP 28/18/I fo. 97 (pay warrant for Peter Francis, 18 Sept. 1644), SP 28/10 fos. 21 and 3o (billeting account for Robert Woodward, 1 Aug. to 2 Sept. 1643 and pay warrant for William Alley/Allen, 14 Sept. 1643), SP 28/16/I fo. 108 (pay warrant for Timothy Langley, 26 June 1644), SP 28/20 fo. $4^{1}$ (Reading garrison accounts, 1644), SP 28/29/II fos. 334-5 (pay warrant for John Franklin, 11 Apr. 1645), SP 28/121A fo. 133 (Warwick garrison accounts, 1643-4), SP 28/122/II fo. 367 (payment to Stephen Beddard, 14 Apr. 1645), SP 28/126 fos. 10 and $64 \mathrm{v}$ (Windsor garrison accounts, $1644^{-}-5$ ); SP 28/127 fo. 31 ov (Aylesbury garrison accounts, 1643-4), SP 28/ 128 /xxvi fo. 6 (Plymouth garrison accounts, 1645-8), SP 28/129/viI fos. 6v-7 (Portsmouth garrison accounts, 1642-3), SP 28/ 146/XVIII fo. 27 (pay warrant to Mr Bromfield, 14 Oct. 1643), SP 28/145 fo. 249 (payment to Mr Burton, 31 July 1642); JHC, III (1643-4), p. 658; Guildhall Library (GL), MS 5265/1 (Register of freedom admissions, 1522-1665); GL, MS 5255/1 (Wardens' accounts and audit books, 1603-59), unpag. 
Table 3 Surgeons in the Eastern Association

\begin{tabular}{lll}
\hline \hline $\begin{array}{l}\text { Freeman of the London Barber- } \\
\text { Surgeons' Company }\end{array}$ & $\begin{array}{l}\text { Identifiable surgeons not in the London Barber- } \\
\text { Surgeons' Company }\end{array}$ & $\begin{array}{l}\text { Other unidentifiable } \\
\text { surgeons }\end{array}$ \\
\hline Matthew Birchinall & Richard Barton & Mr Berry \\
Enoch Bostock (translated) & Edward Atkinson & Mr Boyer \\
?Samuel Browne & Joyce Bennett & Mr Fudge \\
Bradbury Clarke & Timothy Bond & Mr Goodrich \\
?William Clarke & James Bowman & Mr Gutteridge \\
Joseph Echell & Thomas Bullock & Mr Lindsey \\
?Mr [?Richard] Elliot & Jonathan Crosse & Mreyring \\
Thomas Fothergill (by redemption) & Edward Elsing & Mr Sandford \\
?Mr [?Christopher] Gouldesborough & Basset Jones & Mr Siler \\
?John Nichols & William Kseamd & Mr Timms \\
Nicholas Seres & Francis Loyal & \\
John Waylett & Henry Lloyd & \\
John Wyther & William Le Neave & \\
& Ar. Purlevant & \\
& Abraham Roe & \\
& Lodowick Sommervell & \\
& Thomas Tylor & \\
& John Vandale & \\
& Andrew Vanderlash &
\end{tabular}


Table 3 (Cont.)

\begin{tabular}{lll}
\hline \hline $\begin{array}{l}\text { Freeman of the London Barber- } \\
\text { Surgeons' Company }\end{array}$ & $\begin{array}{l}\text { Identifiable surgeons not in the London Barber- } \\
\text { Surgeons' Company }\end{array}$ & $\begin{array}{l}\text { Other unidentifiable } \\
\text { surgeons }\end{array}$ \\
\hline & John Wasse \\
& Edward Webb \\
\hline \hline
\end{tabular}

Sources: TNA, SP 28/5 fo. 310 (pay warrant for John Waylett, 27 Feb. 1643), SP 28/12/II fo. 204 (pay warrant for Edward Elsing, 21 Feb. 1644), SP 28/13/II fo. 200 (pay warrant to for James Bowman, 4 Sept. 1643, SP 28/14/I fo. 1 8o (account of Thomas Forthergill, Jan. to Apr. 1644), SP 28/15/II fos. 275 and 279 (pay warrants to William Le Neave, 13 May 1644, and Joseph Echell, 14 May 1644 ), SP 28/17/III fos. 348 and 357 (payments to Mr Fudge, 15 Aug. 1644, and Mr Siler, 14 Aug. 1644), SP 28/19/III fos. 346 and 387 (pay warrants for Lodowick Sommervell, 16 Oct. 1644, and Thomas Bullock, 20 Oct. 1644), SP 28/20/II fo. 181 (pay warrant for John Vandale, 5 Nov. 1644), SP 28/20/III fo. 353 (pay warrant for William Kseamd, 24 Nov. 1644), SP 28/2 1/I fos. 49, 54, 76, and 101 (payments to William Clarke, 14Jan. 1645, Timothy Bond, 10 Dec. 1644, Mr Sandford, 18 Sept. 1644, and Edward Atkinson, 12 Dec. 1644 ), SP 28/23/I fos. 231 and 288 (payments to Mr Lindsey and Mr Gouldesborough, Mar. 1645), SP 28/24/I fo. 74 (payment to Mr Gutteridge, May 1644), SP 28/24/Iv fo. 519v-520 (payments to Mr Goodrick, 23 Mar. 1645, and Edward Webb, 6 July 1644), SP 28/25/I fos. 135 and 138 (payments to Bradbury Clarke, 13 Aug. 1644, and Francis Loyal, 31 Aug. 1644), SP 28/25/II fos. 217 and 311 (payments to John Walker, 9 Oct. 1644, and Thomas Tylor, 20 June 1644), SP 28/25/III fos. 1 and 403 (pay warrants for Jonathan Crosse, 27 Aug. 1644, and Nicholas Seres, 25 Mar. 1644, SP 28/26/III fos. 312 and 320 (pay warrants for Andrew Vanderlash, 18 Jan. 1645, and Enoch Bostock, 2 Aug. 1644), SP 28/35/III fo. 371 (payments to Henry Lloyd, Ar. Purlevant, and Basset Jones, undated), SP 28/121A/III fos. 13 and 15 (Burleigh House garrison accounts $1643-4$ ), SP 28/121B/II fos. $15^{6}$ and $15^{8}$ (Newport Pagnell garrison accounts, 1645), SP 28/122/I fo. 171 (payment to John Wasse, 2 May 1645), SP 28/127/1 fo. 18 (Newport Pagnell garrison accounts, 1646), SP 28/133/I fo. 98 (King's Lynn garrison accounts, 1646), SP 28/144/III fo. 7a (payment to Samuel Browne, Jan. 1645), SP 28/145 fos. 264-84 (Eastern Association account book, 1644-5); GL, MS 5265/1; GL, MS $5255 / 1$. 
Table 4 Surgeons in the Southern Association

\begin{tabular}{|c|c|c|}
\hline $\begin{array}{l}\text { Freeman of the London } \\
\text { Barber-Surgeons' } \\
\text { Company }\end{array}$ & $\begin{array}{l}\text { Identifiable surgeons } \\
\text { not in the London } \\
\text { Barber-Surgeons' } \\
\text { Company }\end{array}$ & $\begin{array}{l}\text { Other unidentifiable } \\
\text { surgeons }\end{array}$ \\
\hline ?Richard Allen & Thomas Aisernelry & Mr Bicknor \\
\hline Alexander Aurelius & James Brichett & $\begin{array}{l}\text { Mr Hannam } \\
\text { (?Elnathan Hannam) }\end{array}$ \\
\hline $\begin{array}{l}\text { Henry Cleare Jnr } \\
\text { ?John Watts }\end{array}$ & $\begin{array}{l}\text { Nicholas King } \\
\text { Peter Ray } \\
\text { James Stocke }\end{array}$ & Mr Harris \\
\hline
\end{tabular}

Sources: L. Spring, Waller's army (Farnham, 2007), pp. 75, 79, 109, 129, 156 , and 159-6o; TNA, SP 28/35/IV fo. 635 (payment to Henry Cleare, 25 Apr. 1645), SP 28/144/v fo. 8oa (payment to Thomas Aisernelry, 19 Aug. 1644); GL, MS $5265 / 1$; GL, MS 5257/5 (Barber Surgeons' Company court minute book, $1621-5^{1)}$, fo. $39^{1}$.

That said, Pelling discovered during her research into the Norwich barbersurgeons that large numbers lay outside the formal procedures of apprenticeship, freedom, and guild membership. ${ }^{89}$ Masters could not enrol an apprentice into a company without paying 'extortionate' fees and many avoided this if possible, whilst the desire to enforce guild procedures varied with time. $9^{\circ}$ Apprenticeships operating outside the auspices of municipal craft companies did not necessarily produce less-skilled surgeons. The Elizabethan military and naval surgeon William Clowes (father of Charles I's serjeant-surgeon), whose treatise on gunshot wounds A proved practice for all young surgeons became a standard work for the generation of Civil War surgeons, had not served a formal apprenticeship in a barber-surgeons' company. ${ }^{91}$ Clowes was not afraid to criticize ignorant surgeons and though he may have been biased because of his own experience, he claimed to know many surgeons who had no formal training but practised 'honestly, carefully, painfully, and skilfully'.92

\section{I I}

It remains to consider how Civil War medical practitioners may have fared in practice. Many of the daily medical conditions that they would have

89 Pelling, Common lot, p. 208.

9o Ibid., pp. 211-12.

$9^{1}$ I. G. Murray, 'Clowes, William (1543/4-1604)', ODNB. Clowes's treatise was reprinted as late as 1637 as A profitable and necessarie booke of observations.

$9^{2}$ Pelling, Common lot, p. 255. 
Table 5 Surgeons in the New Model Army

Identifiable surgeons not in the

London Barber-Surgeons'

Other unidentifiable

Freeman of the London Barber-Surgeons' Company surgeons

?William Alley/Allen
Alexander Aurelius
Samuel Bradshaw
Henry Cleare snr
Henry Cleare jnr
(?James Cleare)
?Edward Cooke
?Mr [?Matthew] Coutch/?Crouch
Thomas Crutchley
Thomas Harding
Giles Hicks (translated)
?Mr [?Edmund] Higgs
Richard Morley
Guy Noble
John Payne
Daniel Pew/Pugh
Robert Rand
Thomas Symonds
Thomas Trapham
Richard Tompkins

Henry Barnwell

Stephen Beddard

Matthew Broad

Humphrey Cole

William Dodd

James Donaldson

Thomas Fothergill

Nathaniel Frankes

Richard Gwyn

Thomas Harvest

Richard Hinges

John Hubbard

Humphrey Hughes

Meredith Jones

Daniel Judd

Thomas Lawrence

Robert Mustow

Valentine Nickson

Francis Prujean

Francis Rishworth
Mr Bettris

Mr Browne

Mr Knowles

Mr Simmes 


\author{
Arnold Sallenoza \\ Isaac Smitheis/Smythes \\ Bonham Spencer \\ Thomas Standford \\ Walter Stephenson \\ Sandys Suter \\ Walter Thompson \\ Mr [?John] Walker \\ Edward Wentworth
}

Sources: TNA, SP 28/30/II fos. 130 and 172 (pay warrants for Mr Browne, 7 May 1648 and James Winter, 6 May 1645 ), SP 28/35/III fos. 344 and 417 (Northampton garrison accounts, SP 28/42/II fo. 18o (quartering for Edward Wentworth, 1646), SP 28/41/III fo. 224 (payment to Thomas Fothergill, 21 Dec. 1646), SP 28/42/IV fo. 580 (payment to Francis Rishworth, 27 July 1646), SP 28/51/I fo. 111 (list of general officers, 1o Feb. 1648), SP 28/53/II fo. 164 (pay warrant for Richard Morley, 17 Apr. 1648), SP 28/53/III fos. 413, 430, 434, 436, and 463 (pay warrants for Walter Stephenson, 17 Apr. 1648, Henry Cleare snr, Richard Tompkins, and Thomas Symonds, 12 Apr. 1648, and Henry Cleare jnr, 24 Apr. 1648), SP 28/54/II fo. 155 (certificate from Valentine Nickson, 12 Apr. 1648), SP 28/54/II (pay warrant for Matthew Broad, 25 May 1648), SP 28/57/IV fo. 538 (quartering for Mr Simmes, 1646), SP 28/ 66/III fo. 475 (payment to Arnold Sallenoza, 25 Mar. 165o), SP 28/67/III fos. 404-22 (pay warrants for Bonham Spencer, Mr Croutch, Mr Bettris, Thomas Crutchley, William Dodd, Mr Knowles, Meredith Jones, Nathaniel Frankes, and Richard Hinges, 2 May 165o), SP 28/67/IV fos. 638-40 (pay warrants for Daniel Judd and Mr Higgs, 28 May 165o), SP 28/70/II fo. 222 (pay warrant for Edward Cooke, 2 Aug. 165o), SP 28/70/III fos. $5^{85}$ and 589 (pay warrants for Daniel Pew/Pugh, 11 Sept. 165o, and Robert Rand, 11 Sept. 1650), SP 28/74/iv fo. 854 (pay warrant for Mr Walker, 22 Feb. 1651), SP 28/77/rv fos. 679-99 and 787 (pay warrants for Thomas Harding, Thomas Harvest, Humphrey Hughes, Henry Barnwell, John Hubbard, Walter Thompson, Isaac Smitheis/Smythes, Thomas Standford, John Payne, Thomas Lawrence, and Sandys Suter, 23 May 1651, and Robert Mustow, 30 May 1651); SP 28/124/ II fos. 316 and 383 (musters at Newcastle, 1648), SP 28/124/II fo. 332 (list of officers who left Colonel Graves's regiment, 14 June 1648), SP 28/125/I fo. 15 (Tynemouth Castle garrison accounts), SP 28/125/II fo. 197 (Tynemouth Castle garrison accounts), SP 28/126/I fos. 73v and 13ov-131 (Aylesbury garrison accounts, July 1646 to Dec. 1646); Gruber von Arni, Justice to the maimed soldier, p. $80 ;$ GL, MS $5265 / 1$. 
Table 6 Surgeons in royalist armies

\begin{tabular}{lll}
\hline \hline $\begin{array}{l}\text { Freeman of the London } \\
\text { Barber-Surgeons' } \\
\text { Company }\end{array}$ & $\begin{array}{l}\text { Identifiable surgeons } \\
\text { not in the London } \\
\text { Barber-Surgeons' } \\
\text { Company }\end{array}$ & $\begin{array}{l}\text { Other } \\
\text { unidentifiable } \\
\text { surgeons }\end{array}$ \\
\hline William Clowes & Richard Addis & $\begin{array}{l}\text { Mr Bowman } \\
\text { Thomas Brugis }\end{array}$ \\
$\begin{array}{l}\text { Edward Hales } \\
\text { Henry Johnson }\end{array}$ & $\begin{array}{l}\text { Stephen Fosset } \\
\text { John Knight }\end{array}$ & $\begin{array}{l}\text { Mr Spooner } \\
\text { Thorneton }\end{array}$ \\
Edward Molins & Gervis Nevill & \\
?umphrey Painter & James Rummage \\
Mr [?Richard] Watson & John Shelvock & \\
Richard Wiseman & James Thornehill & \\
\hline \hline
\end{tabular}

Sources: Green, Committee for compounding, II, 1567 , III, pp. 2290-1; TNA, PROB 11 / 197 fos. 66v-67r (will of Edward Hales, 7 July 1646); J. Birch, Military memoir of Colonel John Birch, ed. T. Webb and J. Webb (London, 1873), p. 208; Atherton, 'Royalist garrison of Lichfield Close', pp. 82 and 86-7; Morris, 'Molins, Edward', $O D N B$; TNA, SP 28/143 fos. 20a and 66a; Wiseman, Severall chirurgicall treatises, passim; Gruber von Arni, Justice to the maimed soldier, pp. 23, 26, and 29; Willis Bund, ed., Diary of Henry Townshend, p. 153; Worton, 'War effort in Shropshire', p. 217 ; GL, MS $526_{5} / 1$.

encountered, such as ulcers, fractures, 'fluxes of the belly', dislocations, and even amputations, would have been common civilian complaints. However, Wiseman contended that 'Wounds made by Gun-shot are the most complicate sort of Wounds that can be inflicted', a notion with which John Woodall concurred.93 Woodall, surgeon-general to the East India Company and a former military surgeon, recalled that when the privy council instructed the London Barber-Surgeons' Company to impress surgeons experienced in curing gunshot wounds for the voyage to the Île de Ré, 'by reason of that long and happy peace that our Nation had enioyed, many good Surgeons being put to it at the first, were likely to have been found somewhat to seek therein'. He thought the same could be said on the eve of the Civil Wars.94

With war against Scotland looming in 1639 , Woodall republished The surgeons mate. Like Clowes's treatise, Woodall's work was probably indispensable to Civil War surgeons. The royalist surgeon Thomas Brugis certainly admitted to following Woodall's methods.95 The wide availability of continental literature in

\footnotetext{
93 Wiseman, Severall chirurgicall treatises, p. 409; Woodall, Surgeons mate, p. 94.

94 Woodall, Surgeons mate, preface to 'Viaticum', sig. q2.

95 T. Brugis, Vade mecum (London, $165^{1}$ ), p. 105 .
} 
Britain prior to the Civil Wars is a well-known phenomenon to military historians..$^{6}$ Yet, Civil War medics too were well read in the medical works of leading continental military practitioners. The works of Wiseman and James Cooke (surgeon to the parliamentarian garrison at Warwick) incorporated the techniques of men like Hieronymus Fabricius, Ambroise Paré, and Johannes Scultetus. 97 The literature of the Military Revolution was not merely confined to drillbooks.

Some Civil War surgeons may have gained previous experience by enlisting in the English regiments serving in Protestant armies on the continent. No evidence of this has yet been traced, though some were fortunate enough to learn from those with prior military experience. For example, the younger Clowes had been apprenticed to his father, whilst Timothy Langley (staff surgeon to Essex's army from June 1644) had been apprenticed to Henry Boone, Woodall's pupil. $9^{8}$ Several surgeons honed their skills by serving in the war against Scotland, including Loe and Langley.99 The Civil Wars were themselves a learning experience. Henry Johnson, surgeon to the king's own troop of horse, took his apprentice William Gill with him on campaign in the Civil Wars, whilst many of the unnamed surgeons' mates in pay warrants must also have been apprentices. ${ }^{100}$

It was not just apprentices who learnt on the job. As Cook argued for the later seventeenth century, military service not only provided a training ground for medical practitioners but also reinforced the growing trend towards empirical, practical, 'clinical' medicine. ${ }^{101}$ Military practitioners dealt with large numbers of men at once and thus had little time for the physic of learned physicians, which sought the causes of disease in the unique physiological conditions of each person's constitution. Instead, they sought specific cures for specific diseases, which led to uniformity in diagnosis and treatment. ${ }^{102}$ Cook himself noted the involvement of Civil War practitioners such as John French in the new 'chemical medicine', whilst according to Stephen Rutherford, the writings of Civil War practitioners are examples of 'evidence-based practice'. These men demonstrated good understandings of physiology, anatomy, antiseptics, infection control, and pharmacology, and embraced forward-thinking and scientific

$9^{6}$ B. Donagan, 'Halcyon days and the literature of war: England's military education before 1642', Past and Present, 147 (1995), pp. 65-100, at p. 97.

97 Wiseman, Severall chirurgicall treatises, pp. 66, 122 and 341; J. Cooke, Mellificium chirurgie (London, 1648), pp. [x]-[xi] and 28.

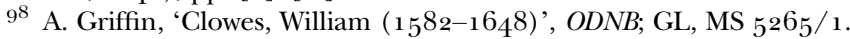

99 Peacock, ed., Army lists, pp. 74 and 83 . 'Trinity' is almost certainly a misreading of 'Timothy'.

${ }^{100}$ Birch, Military memoir, p. 208.

${ }^{101}$ Cook, 'Practical medicine and the British armed forces', p. 16.

${ }^{102}$ Ibid., p. 2. 
principles that enabled them to become 'pioneers of medical practice'. ${ }^{103}$ Men like the captain of a company of dragoons on whom Wiseman experimented with an innovative dressing survived who otherwise would have perished. ${ }^{104}$

That said, even the most competent practitioners could do little in the face of the epidemics that ripped through soldiers' quarters and paralysed armies. ${ }^{105}$ Failure to treat disease undoubtedly had a severe impact on an army's capability, though military historians must be cautious of exaggerating its effects. As Malcolm Wanklyn argued, tactical contingency was also important. He pointed out that whilst the New Model Army was severely hit by the 'New disease' (probably typhus) during winter 1645, that army still outnumbered their opponents by a considerable margin but it took Sir Thomas Fairfax four months to force the surrender of the royalist army in the west and another two months to capture the major garrisons. ${ }^{106}$

No doubt some surgeons were incompetent. Firth cited the case of Mr Fish, a former surgeon's mate who had been forced to resign to avoid court martial 'for some miscarriages' but was later appointed surgeon of the artillery in Scotland. Monck begged Cromwell to rescind Fish's commission, complaining that Fish was 'unfit to take such an employ upon him' because he was 'never bound prentice to the profession'. ${ }^{107}$ Yet, Monck's letter infers that there were plenty of other competent surgeons who could have been appointed in Fish's stead. Elsewhere, Holmes backed up his claim that 'a number of chirurgeons were unqualified' with an Indemnity Committee case in which James Bowman, surgeon to the earl of Manchester, was prosecuted by Eber Birch of Beverley for using physic as well as surgery. ${ }^{108}$ However, although surgeons were theoretically confined to performing outward manual procedures, they had long assumed certain privileges in the practice of physic. This concerned physicians, who jealously guarded their right to administer internal medicine. ${ }^{109}$ Woodall argued that in military contexts where a physician may not be available, it was 'uncharitable to forbid an expert Surgeon at any time, or in any place, the use of the instruments and medicines which are necessary to his art, for the curing of his patients'. ${ }^{10}$ It appears that Bowman was not so much unqualified

103 Ibid., p. $1_{5}$; S. M. Rutherford, 'Ground-breaking pioneers or dangerous amateurs? Did early modern surgery have any basis in medical science?', in I. Pells, ed., New approaches to the military history of the English Civil War (Solihull, 2016), pp. ${ }_{53}-85$, at p. ${ }_{5}^{6 .}$

104 Wiseman, Severall chirurgicall treatises, p. 378.

105 B. Donagan, 'The casualties of war: treatment of the dead and wounded in the English Civil War', in I. Gentles, J. Morrill, and B. Worden, Soldiers, writers and statesmen of the English Revolution (Cambridge, 1998), pp. 114-32, at pp. 120-1.

106 Wanklyn, Warrior generals, p. 177.

${ }^{107}$ Firth, Cromwell's army, p. 254.

${ }_{108}$ Holmes, Eastern Association, pp. 174 and 284 n; TNA, SP 24/35 fo. 363 (Bowman v. Birch, 15 Sept. 1648).

109 Pelling, Medical conflicts, p. 53.

110 Woodall, Surgeons mate, pp. [xv]-[xvi]. 
as, like many others amongst the Indemnity papers, being prosecuted for the necessities of war.

Further investigation into the case of Edward Cooke is similarly revealing. Firth highlighted that Cooke had been accused of incompetence and neglect of his patients. ${ }^{11}$ Cooke had served as surgeon-general to the army in Ireland but this case refers to the Flanders campaign conducted by the Protectorate in $1657-9 \cdot{ }^{12}$ Cooke had been sent to Dover to supervise the reception of casualties from Mardyke and Dunkirk but his efforts were hampered by the poor planning and lack of funding that surrounded the campaign. ${ }^{113}$ Complaints arose about the standard of care in Dover and Cooke was forced to answer for it. In his defence, he appended a statement signed by thirty-one of his patients, who testified to his personal skill and care. ${ }^{114}$ Moreover, forty wounded soldiers in Dover subsequently petitioned to be removed to London not due to neglect from Cooke and his army assistants, by whom they 'bin Carefully and duely dressed', but because they had been recently transferred to the care of local civilian surgeons, one of whom was 'a public Drunkard' and the other 'stricken in yeares'. ${ }^{15}$ The Dover debacle, coupled with criticisms from Wiseman of civilian surgeons, illustrates that civilian medics were used to supplement army practitioners to spread the workload in garrison towns, not, as Firth maintained, because the latter 'were not remarkably skilful'. ${ }^{16}$ This is not to deny that parliament dispatched leading London medics when senior officers were sick or wounded, such as when Skippon was wounded at Naseby, though the importance of that victory prompted parliament to ensure that regimental medics had the resources to deliver exemplary care to all the wounded. ${ }^{117}$

\section{IV}

James Wheeler argued that prior to the Civil Wars, 'while the English were abreast of many of the tactical and technological aspects of the continental Military Revolution, they had still failed to undertake the interrelated financial and administrative changes which were essential and integral longterm parts of that process'. It was not until the Civil Wars that these changes

111 Firth, Cromwell's army, pp. 254-5.

112 Not the same man who served in Essex's army, who was dead by Dec. 1646: TNA, SP 28/ 41 I fo. 79 (receipt for surgery chest, 3 Dec. 1646).

113 Gruber von Arni, Justice to the maimed soldier, pp. 116-18.

114 Bodleian Library, Rawlinson MS, A, LX, fos. 323-6 (examination of Edward Cooke, 7 Aug. $1658)$.

${ }_{115}$ Gruber von Arni, Justice to the maimed soldier, p. 117 ; TNA, SP $18 / 182$ fo. 147 (petition from the sick and wounded in Dover, 2 Sept. 1658).

${ }_{116}$ Wiseman, Severall chirurgicall treatises, p. 408; Firth, Cromwell's army, p. 255.

117 I. Pells, "Stout Skippon hath a wound": the medical treatment of parliament's infantry commander following the battle of Naseby', in A. Hopper and D. Appleby, eds., Battle-scarred: mortality, medical care and military welfare in the British Civil Wars (Manchester, 2018). 
were implemented. ${ }^{118}$ Wheeler's argument applies as much to frontline medical provision as to any other aspect of the Military Revolution. Many features of Civil War regimental medical provision had been trialled previously but it was not until that conflict (and through the implementation of the weekly assessments and the excise) that the continental military medical practices highlighted by Cook were implemented in Britain for any sustained period of time. If warfare drives medical advancement as the cliché suggests, then the experience of the Civil Wars is a reminder that progression is not based solely on the battlefield environment but also on the bureaucratic procedures that supported it. The raising of armies might provide many new opportunities for practitioners to improve their knowledge and treatment of military conditions, as well as develop new techniques in response to the challenges posed by the evolution of weaponry and engage in aspects of medicine beyond their strictly defined civilian roles (the practice of physic by surgeons, for example). However, such opportunities were more likely to have been taken up by practitioners if the promise of sufficient material compensation for their efforts was fulfilled.

That said, as Gavin Robinson maintained, during the Civil Wars resources were often contingent on political circumstances and the outcome of battles. Reliable tax revenues did not guarantee success and administrators had to work hard to make victory possible. ${ }^{19}$ Parliament had constructed sustainable tax systems to support its armies in a long war by mid-1 643 but in autumn 1644 , it took the humiliating surrender at Lostwithiel to jolt parliament into supplying their surgeons. The recognition that resources were contingent on political circumstances explains why the evolution of British military medicine was a process of ebbs and flows, rather than teleological development. What the Glorious Revolution resolved, as Wheeler again argued, was the difficulties in government finance which stemmed from the conflict of political philosophies between the Stuarts and their parliaments that had re-emerged to plague English military operations at the Restoration. ${ }^{120}$ This political shift no doubt had as profound implications for the administration of military medicine as the rest of military administration. Yet if a revolution may build upon previous advances, and its impact may not be fully realized until later, but it occurs where a paradigm shift takes place that qualitatively reshapes subsequent affairs, then it is in the Civil Wars that we must place the revolution in British military medicine. ${ }^{121}$

By placing Civil War regimental medics in the context of what is known about seventeenth-century practitioners more generally, it seems that they differed little from their civilian colleagues, in terms of their education and training,

118 J. S. Wheeler, The making of a world power (Stroud, 1999), p. 16.

119 G. Robinson, Horses, people and parliament in the English Civil War (Abingdon, 2016), p. 3.

120 Wheeler, Making of a world power, p. 20.

${ }^{21}$ Ibid., pp. 6-9. 
whilst a medical career in the army was potentially a lucrative one. With this in mind, it is difficult to argue that the armies habitually enlisted substandard practitioners. No doubt some were more skilled than others but the wars provided an environment in which the innovative could flourish. Of the $5^{80}$ parliamentarian wounded who received medical treatment in Northampton in the immediate aftermath of the battle of Naseby, only forty-six ( 7.93 per cent) were subsequently noted 'mortuus est'. ${ }^{122}$ Lack of comparable evidence from the beginning of the wars makes it difficult to determine how far the survivors had benefited from observation-based practice conducted over the years of sustained warfare but it does not seem unreasonable to suggest that this may have been the case. Moreover, as Rutherford pointed out, the numerous maimed soldiers who petitioned for financial relief from the state during the Civil War years had survived severe and often multiple injuries. ${ }^{123}$ Some claimed relief as late as the 1 7oos, showing that they survived their injuries for decades afterwards. ${ }^{124}$ Indeed, it is not known what happened to the soldier from the siege of Taunton with which this article opened but he was still alive a week later when Wiseman left him to move on with the rest of the army. ${ }^{125}$

122 TNA, SP $28 / 173$ / I fos. 1a-18a (payments to the sick and wounded that came into Northampton since 14 June 1645).

123 Rutherford, 'Ground-breaking pioneers', p. $18_{3}$.

124 West Yorkshire Archive Service, QS1/45/3/6 (petition of William Walker, 1706), QS1/ 47/8/6 (petition of William Hilton, 1708), and QS1/48/3/6 (petition of John Genn, 1709).

125 Wiseman, Severall chirurgical treatises, p. 403; Carlton, Going to the wars, p. 226. 